Article

\title{
Flame-Spray-Made Undoped Zinc Oxide Films for Gas Sensing Applications
}

\author{
Nittaya Tamaekong ${ }^{1}$, Chaikarn Liewhiran ${ }^{2}$, Anurat Wisitsoraat ${ }^{3}$ and Sukon Phanichphant ${ }^{1, *}$ \\ 1 Nanoscience Research Laboratory, Department of Chemistry, Faculty of Science, Chiang Mai \\ University, Chiang Mai, 50200, Thailand; E-Mail: doramon_koygy@hotmail.com (N.T.) \\ 2 Department of Materials Science, Faculty of Science, Chiang Mai University, Chiang Mai, 50200, \\ Thailand; E-Mail: chaikarn_1@yahoo.com (C.L.) \\ 3 National Electronics and Computer Technology Center, Pathumthani, 12120, Thailand; \\ E-Mail: anurat.wisitsoraat@nectec.or.th (A.W.) \\ * Author to whom correspondence should be addressed; E-Mail: sphanichphant@yahoo.com; \\ Tel.: +6-681-882-7977; Fax: +66-53-892-277.
}

Received: 7 July 2010; in revised form: 16 August 2010 / Accepted: 20 August 2010 /

Published: 23 August 2010

\begin{abstract}
Using zinc naphthenate dissolved in xylene as a precursor undoped $\mathrm{ZnO}$ nanopowders were synthesized by the flame spray pyrolysis technique. The average diameter and length of $\mathrm{ZnO}$ spherical and hexagonal particles were in the range of 5 to $20 \mathrm{~nm}$, while $\mathrm{ZnO}$ nanorods were found to be $5-20 \mathrm{~nm}$ wide and $20-40 \mathrm{~nm}$ long, under $5 / 5$ (precursor/oxygen) flame conditions. The gas sensitivity of the undoped $\mathrm{ZnO}$ nanopowders towards 50 ppm of $\mathrm{NO}_{2}, \mathrm{C}_{2} \mathrm{H}_{5} \mathrm{OH}$ and $\mathrm{SO}_{2}$ were found to be 33, 7 and 3 , respectively. The sensors showed a great selectivity towards $\mathrm{NO}_{2}$ at high working temperature (at $300{ }^{\circ} \mathrm{C}$ ), while small resistance variations were observed for $\mathrm{C}_{2} \mathrm{H}_{5} \mathrm{OH}$ and $\mathrm{SO}_{2}$, respectively.
\end{abstract}

Keywords: undoped $\mathrm{ZnO}$; flame spray pyrolysis; $\mathrm{NO}_{2} ; \mathrm{C}_{2} \mathrm{H}_{5} \mathrm{OH} ; \mathrm{SO}_{2}$; gas sensor

\section{Introduction}

Zinc oxide has attracted increased attention during the last few years due to the possibility of its relatively simple transformation into various nanoscale structures. Nanostructures like rods and particles 
have become the most promising research materials because of their wide range of applications. Different techniques, namely sol-gel [1], spray pyrolysis [2], hydrothermal method [3,4], electrospinning [5], thermal evaporation [6,7], etc. [8-13] are prevalent for the synthesis of zinc oxide nanoparticles and nanorods. In the present work, nanorods and nanoparticles have been prepared by flame spray pyrolysis (FSP), a promising technique for the synthesis of high purity nano-sized materials with controlled size and crystallinity in a single step. This was systematically investigated by using an external-mixing gasassisted atomizer supported by six premixed methane-oxygen flamelets [14].

Semiconducting metal oxide sensors have been extensively studied due to their simple preparation and high sensitivity under ambient conditions [15-20]. Zinc oxide ( $\mathrm{ZnO})$, an n-type metal oxide semiconductor sensing material with a wide band gap $(E \mathrm{~g}=3.37 \mathrm{eV}$ at $300 \mathrm{~K})$, has attracted much attention due to its high chemical stability, low cost, and good flexibility in fabrication. It was found that $\mathrm{ZnO}$ exhibits pronounced gas sensing properties towards many toxic/non-toxic gases such as $\mathrm{NO}_{2}$, $\mathrm{SO}_{2}$, ethanol, etc. [21-31]. A summary on the sensing properties toward $\mathrm{NO}_{2}$, ethanol $\left(\mathrm{C}_{2} \mathrm{H}_{5} \mathrm{OH}\right)$ and $\mathrm{SO}_{2}$ gases of the undoped $\mathrm{ZnO}$ prepared by several synthetic methods is shown in Table 1.

Table 1. A summary on the gas sensing properties of differently-prepared undoped $\mathrm{ZnO}$ for $\mathrm{NO}_{2}$, ethanol $\left(\mathrm{C}_{2} \mathrm{H}_{5} \mathrm{OH}\right)$ and $\mathrm{SO}_{2}$ gases.

\begin{tabular}{|c|c|c|c|c|}
\hline Authors [ref.] & Method & Nanoparticles & Gas concentration & Sensitivity \\
\hline Ghimbeu et al. [21] & $\begin{array}{l}\text { Electrostatic spray } \\
\text { deposition (ESD) } \\
\text { technique }\end{array}$ & Undoped $\mathrm{ZnO}$ & $1 \mathrm{ppm}$ of $\mathrm{NO}_{2}$, at $300^{\circ} \mathrm{C}$ & $\sim 1.84$ \\
\hline Cho et al. [22] & Hydrothermal & Undoped $\mathrm{ZnO}$ & $1 \mathrm{ppm}$ of $\mathrm{NO}_{2}$, at $300^{\circ} \mathrm{C}$ & $\sim 1.8$ \\
\hline Sadek et al. [23] & $\begin{array}{l}\text { Conventional solid-state } \\
\text { method }\end{array}$ & Undoped $\mathrm{ZnO}$ & $10 \mathrm{ppm}$ of $\mathrm{NO}_{2}$, at $350^{\circ} \mathrm{C}$ & $\sim 1.81$ \\
\hline Lupan et al. [26] & A solution method & Undoped $\mathrm{ZnO}$ & $100 \mathrm{ppm}$ of $\mathrm{SO}_{2}$ & $<0.5$ \\
\hline Singh et al. [28] & A simple chemical route & Undoped $\mathrm{ZnO}$ & $\begin{array}{l}250 \mathrm{ppm} \text { of ethanol, at } 400,600 \\
\text { and } 800{ }^{\circ} \mathrm{C}\end{array}$ & $\begin{array}{l}\sim 6.5,5.6 \\
\text { and } 4,\end{array}$ \\
\hline Hieu et al. [31] & Thermal evaporation & Undoped $\mathrm{ZnO}$ & $500 \mathrm{ppm}$ of ethanol, at $300^{\circ} \mathrm{C}$ & 5.3 \\
\hline \multirow{3}{*}{ Present work } & \multirow{3}{*}{$\begin{array}{l}\text { Flame spray pyrolysis } \\
\text { (FSP) }\end{array}$} & \multirow{3}{*}{ Undoped $\mathrm{ZnO}$} & 1,5 and $10 \mathrm{ppm}$ of $\mathrm{NO}_{2}$, at $300^{\circ} \mathrm{C}$ & $\begin{array}{l}\sim 2.7,6.2 \\
\text { and } 11.8\end{array}$ \\
\hline & & & $100 \mathrm{ppm}$ of $\mathrm{SO}_{2}$, at $300{ }^{\circ} \mathrm{C}$ & $\sim 2.8$ \\
\hline & & & $\begin{array}{l}200,300 \text { and } 500 \mathrm{ppm} \text { of ethanol, } \\
\text { at } 300{ }^{\circ} \mathrm{C}\end{array}$ & $\begin{array}{l}\sim 18.2,22.4 \\
\text { and } 27.5\end{array}$ \\
\hline
\end{tabular}

Great interest in improving the gas sensitivity as well as selectivity and in decreasing the working temperature has been witnessed. Nitrogen dioxide $\left(\mathrm{NO}_{2}\right)$ is considered a common air pollutant produced during combustion in automotive engines, industrial factories, and power plants. Therefore, the development of stable $\mathrm{NO}_{2}$ gas sensors that can detect extremely low concentrations of $\mathrm{NO}_{2}$ with high sensitivity is highly desirable [32]. In this study, undoped $\mathrm{ZnO}$ nanopowders have been prepared by the flame spray pyrolysis process and their gas sensing responses towards different gases have been comparatively examined. In particular, three types of sensors were tested under oxidizing and reducing gases, like nitrogen dioxide, ethanol and sulfur dioxide. 


\section{Experimental}

\subsection{Particle synthesis and characterization}

Zinc naphthenate (Aldrich, $8 \mathrm{wt} \% \mathrm{Zn}$ ) was used as a precursor. The precursor was dissolved in xylene (Carlo Erba, 98.5\%) to obtain a $0.5 \mathrm{~mol} / \mathrm{L}$ precursor solution. In a typical run, the precursor was fed into a FSP reactor by a syringe pump with a rate of $5 \mathrm{~mL} / \mathrm{min}$ while $5 \mathrm{~L} / \mathrm{min} \mathrm{O}_{2}$ was being dispersed (5/5 flame). The gas flow rates of methane and $\mathrm{O}_{2}$ supporting flamelets were 1.19 and $2.46 \mathrm{~L} / \mathrm{min}$, respectively. The pressure drop at the capillary tip was kept constant at 1.5 bars by adjusting the orifice gap area at the nozzle.

The flame height was observed to be approximately $10-12 \mathrm{~cm}$. The sample showed a yellowishorange flame. The liquid precursor mixture was rapidly dispersed by a gas stream and ignited by a premixed methane/oxygen flame. After evaporation and combustion of precursor droplets, particles are formed by nucleation, condensation, coagulation and coalescence. Finally, the nanoparticles were collected on glass microfiber filters with the aid of a vacuum pump. The undoped $\mathrm{ZnO}$ nanopowders were characterized by X-ray diffraction (XRD), scanning electron microscopy (SEM) and transmission electron microscopy (TEM). Specific surface area $\left(S S A_{\mathrm{BET}}\right)$ of the nanoparticles was also investigated by nitrogen adsorption (BET analysis).

\subsection{Sensing film preparation and characterization of the gas sensing properties}

The undoped $\mathrm{ZnO}$ sensing film was prepared by mixing the nanoparticles into an organic paste composed of ethyl cellulose and terpineol, which acted as a vehicle binder and solvent, respectively. The resulting paste was spin-coated on $\mathrm{Al}_{2} \mathrm{O}_{3}$ substrates with predeposited interdigitated $\mathrm{Au}$ electrodes. The films were then annealed at $400{ }^{\circ} \mathrm{C}$ for $2 \mathrm{~h}$ (with heating rate of $2{ }^{\circ} \mathrm{C} / \mathrm{min}$ ) for binder removal. The morphology and the cross section of sensing films were analyzed by SEM.

The gas-sensing characteristics of the undoped $\mathrm{ZnO}$ nanoparticles towards $\mathrm{NO}_{2}, \mathrm{C}_{2} \mathrm{H}_{5} \mathrm{OH}$ and $\mathrm{SO}_{2}$ were characterized. The flow through technique was used to test the gas-sensing properties of thin films. A constant flux of synthetic air of $2 \mathrm{~L} / \mathrm{min}$ was mixed with desired concentrations of pollutants. All measurements were conducted in a temperature-stabilized sealed chamber at $20{ }^{\circ} \mathrm{C}$ under controlled humidity. The external $\mathrm{NiCr}$ heater was heated by a regulated dc power supply to different operating temperatures. The operating temperature was varied from $200{ }^{\circ} \mathrm{C}$ to $350{ }^{\circ} \mathrm{C}$. The resistances of various sensors were continuously monitored with a computer-controlled system by voltageamperometric technique with $5 \mathrm{~V}$ dc bias and current measurement through a picoammeter. The sensor was exposed to a gas sample for $\sim 5$ minutes for each gas concentration testing and then the air flux was restored for 15 minutes. The concentration of $\mathrm{NO}_{2}, \mathrm{C}_{2} \mathrm{H}_{5} \mathrm{OH}$ and $\mathrm{SO}_{2}$ were varied from 1 to $50 \mathrm{ppm}, 50$ to $100 \mathrm{ppm}$ and 10 to $500 \mathrm{ppm}$, respectively.

\section{Results and Discussion}

\subsection{Particle properties}

Figure 1 shows the XRD patterns of the undoped $\mathrm{ZnO}$ sample. All peaks can be confirmed to correspond to the hexagonal structure of ZnO (JCPDS No. 79-205). 
Figure 1. The XRD patterns of flame-spray-made (5/5) undoped $\mathrm{ZnO}$ nanopowders.

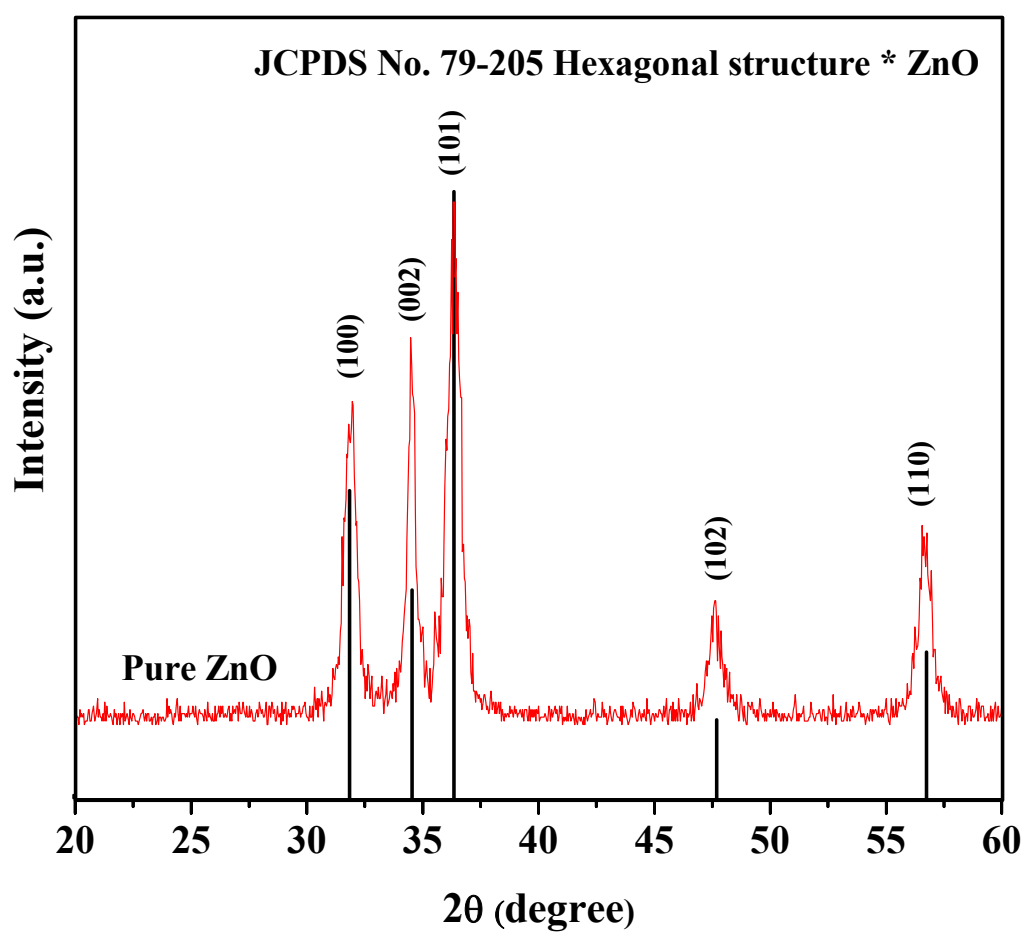

An average BET equivalent particle diameter $\left(d_{\mathrm{BET}}\right)$ was calculated using the average density of $\mathrm{ZnO}$ as shown in Table 2. The accurate particle size and morphology of undoped $\mathrm{ZnO}$ dispersion were confirmed by SEM and TEM images.

Table 2. The specific surface area $\left(S S A_{\mathrm{BET}}\right)$ and $d_{\mathrm{BET}}$ of undoped $\mathrm{ZnO}$ nanoparticles.

\begin{tabular}{|c|c|c|}
\hline Sample & Specific surface area $\left(\boldsymbol{S S} \boldsymbol{A}_{\text {BET }}\right),\left(\mathbf{m}^{2} / \mathbf{g}\right)$ & $\boldsymbol{d}_{\text {BET }}(\mathbf{n m})$ \\
\hline Undoped $\mathrm{ZnO}$ & 78.8 & 13.6 \\
\hline
\end{tabular}

Figure 2 shows the morphology of highly crystalline flame-made (5/5) undoped $\mathrm{ZnO}$ nanoparticles from SEM analysis. The SEM micrograph clearly showed nanostructural homogeneities and remarkably different morphologies of the undoped $\mathrm{ZnO}$ nanoparticles synthesized by the FSP technique. The SEM result showed the presence of agglomerated nanospheres with an average diameter of 10-20 nm. Therefore, from this observation only the rough morphology was found. Nevertheless, the accurate sizes and morphology of the nanoparticles can be estimated from the TEM analysis. While the SEM images provide 3-D morphology and estimated particle sizes, TEM images can reveal internal structure and a more accurate measurement of particle size and morphology.

Figure 3 shows the TEM-bright-field images of undoped $\mathrm{ZnO}$ nanoparticles. The $\mathrm{ZnO}$ morphologies were revealed to be spherical, hexagonal and rod-like. The presence of $\mathrm{ZnO}$ spherical nanoparticles along with a few nanorods was observed as shown in Figure 3(a). The crystallite sizes of spherical particles were found to be in the range of 5-20 nm whereas the nanorods were found to be ranging from 5-20 nm in width and $20-40 \mathrm{~nm}$ in length. Hexagonal $\mathrm{ZnO}$ nanoparticles with the size of 5-20 nm were also observed, as shown in Figure 3 (b). 
Figure 2. The SEM micrograph of highly crystalline flame-made (5/5) undoped $\mathrm{ZnO}$ nanoparticles.

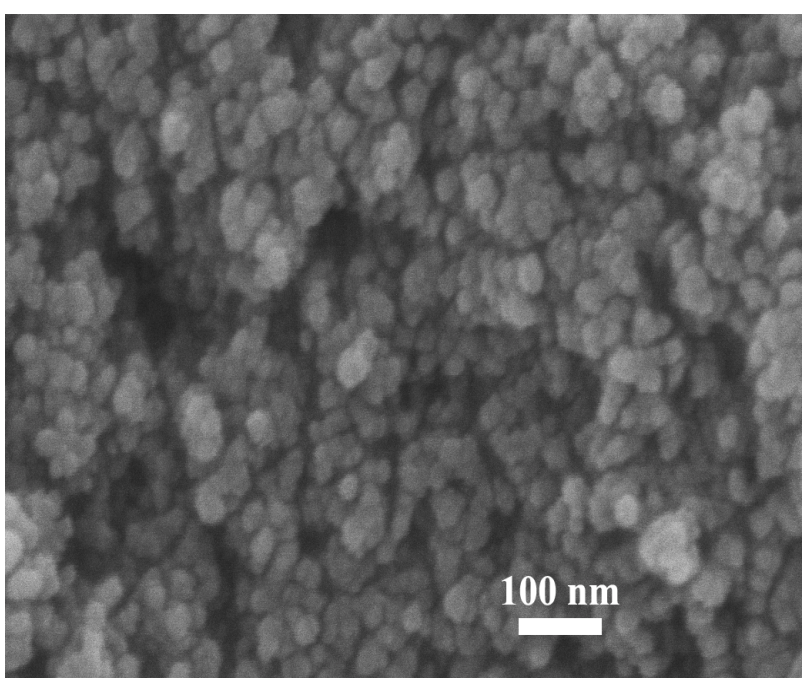

Figure 3. The TEM images of undoped $\mathrm{ZnO}$ morphologies showing the spherical, hexagonal and rod-like shapes.

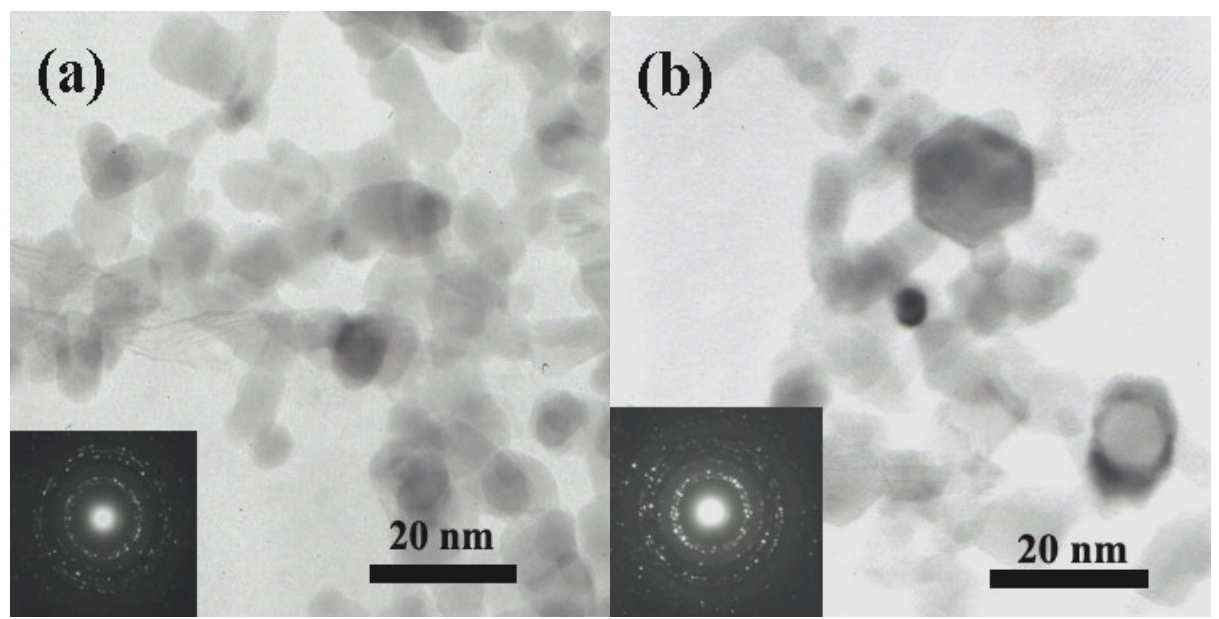

\subsection{SEM sensing layer}

The cross-section, film thickness, and surface morphology of the undoped $\mathrm{ZnO}$ sensing film layer after annealing and sensing test at $300{ }^{\circ} \mathrm{C}$ were observed using SEM analysis, as shown in Figure 4. The thickness of sensing film was approximately $10 \mu \mathrm{m}$ (side view) which benefited tremendously the $\mathrm{NO}_{2}, \mathrm{C}_{2} \mathrm{H}_{5} \mathrm{OH}$ and $\mathrm{SO}_{2}$ gas sensing properties. Irregularities in the film thickness (top view) stem from the spin coating technique. The high density $\mathrm{Al}_{2} \mathrm{O}_{3}$ substrate interdigitated with Au electrodes was also visible. After the annealing process, a denser film layer was formed.

The sensitivity and response time of the thick films of the undoped $\mathrm{ZnO}$ nanoparticles as a function of $\mathrm{NO}_{2}, \mathrm{C}_{2} \mathrm{H}_{5} \mathrm{OH}$ and $\mathrm{SO}_{2}$ concentrations at $300{ }^{\circ} \mathrm{C}$ are shown in Figure 5. In Figure 5(a), it can be seen that the sensitivity toward $\mathrm{NO}_{2}$ is increased considerably at $50 \mathrm{ppm} \mathrm{NO}_{2}$ concentration. The sensitivity and response time for the undoped $\mathrm{ZnO}$ nanoparticles at $50 \mathrm{ppm} \mathrm{NO}_{2}$ concentration were found to be 33 and $7 \mathrm{~s}$, respectively. The sensitivity, however, are decreased considerably by testing the undoped $\mathrm{ZnO}$ sensor with $\mathrm{C}_{2} \mathrm{H}_{5} \mathrm{OH}$ and $\mathrm{SO}_{2}$ at $50 \mathrm{ppm}$ concentration of each gas. The sensitivity of 
7 and 3 with the response time of 94 and $17 \mathrm{~s}$ are obtained at $50 \mathrm{ppm}$ of $\mathrm{C}_{2} \mathrm{H}_{5} \mathrm{OH}$ and $50 \mathrm{ppm}$ of $\mathrm{SO}_{2}$, respectively. It is important to note that the undoped $\mathrm{ZnO}$ nanoparticles behave as an n-type semiconductor with decreased resistance during $\mathrm{NO}_{2}, \mathrm{C}_{2} \mathrm{H}_{5} \mathrm{OH}$ and $\mathrm{SO}_{2}$ gas exposure, which is a typical behavior of $\mathrm{ZnO}$ material [33]. The gas-sensing sensitivity, $S$, is defined as the ratio of $R_{a} / R_{g}$ where $R_{a}$ is the resistance in dry air, and $R_{g}$ is the resistance in test gas. The response time, $T_{\text {res, }}$ is defined as the time required until $90 \%$ of the response signal is reached. The recovery time, $T_{\text {rec }}$, denotes the time needed until $90 \%$ of the original baseline signal is recovered. The sensor behaviors under the operating temperature of $300{ }^{\circ} \mathrm{C}$ versus the $\mathrm{NO}_{2}$ concentrations ranging from 1-50 ppm for the flame-made undoped $\mathrm{ZnO}$ nanoparticles were plotted as shown in Figure 5(a). The changes in resistance of the undoped $\mathrm{ZnO}$ sensor for $\mathrm{C}_{2} \mathrm{H}_{5} \mathrm{OH}$ and $\mathrm{SO}_{2}$ gases under exposure to 50-1,000 ppm of $\mathrm{C}_{2} \mathrm{H}_{5} \mathrm{OH}$ and $10-500 \mathrm{ppm}$ of $\mathrm{SO}_{2}$ during forward cycle at $300{ }^{\circ} \mathrm{C}$ are shown in Figures 5(b,c), respectively.

Figure 4. The SEM micrographs of flame-made undoped $\mathrm{ZnO}$ thick films sensor on an $\mathrm{Al}_{2} \mathrm{O}_{3}$ substrate interdigitated with Au electrodes after annealing and sensing test at $300{ }^{\circ} \mathrm{C}$ in dry air. The film thickness was approximately $10 \mu \mathrm{m}$.

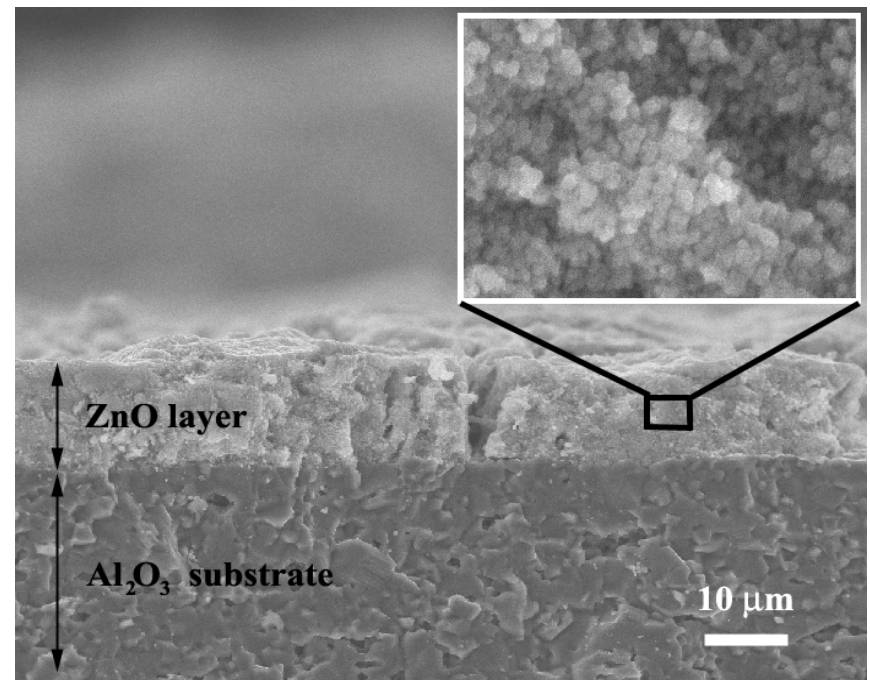

It is well known that the sensitivity of a semiconductor gas sensor is highly influenced by its operating temperature [34,35]. In order to determine the optimum operating temperatures, the response of the undoped $\mathrm{ZnO}$ gas sensor to $50 \mathrm{ppm}$ concentration of nitrogen dioxide, ethanol and sulfur dioxide in air was tested as a function of operating temperature, as shown in Figure 6. It is clear that the responses of three gases tested varied with operating temperature. The sensitivity to $\mathrm{NO}_{2}$ first increased with temperature, up to $300{ }^{\circ} \mathrm{C}$, and then gradually decreased. The maximum sensitivity towards $\mathrm{NO}_{2}$ was 33 , at $300{ }^{\circ} \mathrm{C}$. For ethanol and $\mathrm{SO}_{2}$, the sensitivity continuously increased when operating temperatures varied from 200 to $300{ }^{\circ} \mathrm{C}$, and then decreased. The maximum sensitivities obtained were 7 and 3 , at $300{ }^{\circ} \mathrm{C}$. Therefore, optimal operating temperatures of $300{ }^{\circ} \mathrm{C}$ were chosen for $\mathrm{NO}_{2}$, ethanol and $\mathrm{SO}_{2}$ respectively, to further examine the characteristics of the gas sensor. Results suggest that the undoped $\mathrm{ZnO}$ sensor can act as a multifunctional selective gas sensor, detecting $\mathrm{NO}_{2}$, ethanol and $\mathrm{SO}_{2}$ gases. In other words, the above mentioned sensor can be used as an excellent $\mathrm{NO}_{2}$ sensor at an operating temperature of $300^{\circ} \mathrm{C}$. 
Figure 5. The change in resistance of undoped $\mathrm{ZnO}$ sensor for $\mathrm{NO}_{2}$ (a) $\mathrm{C}_{2} \mathrm{H}_{5} \mathrm{OH}$ (b) and $\mathrm{SO}_{2}$ (c) gases under exposure to oxidizing gas of $\mathrm{NO}_{2}$ and reducing gases of $\mathrm{C}_{2} \mathrm{H}_{5} \mathrm{OH}$ and $\mathrm{SO}_{2}$ during forward cycle at $300{ }^{\circ} \mathrm{C}$, respectively.

Nitrogen dioxide $\left(\mathrm{NO}_{2}\right)$

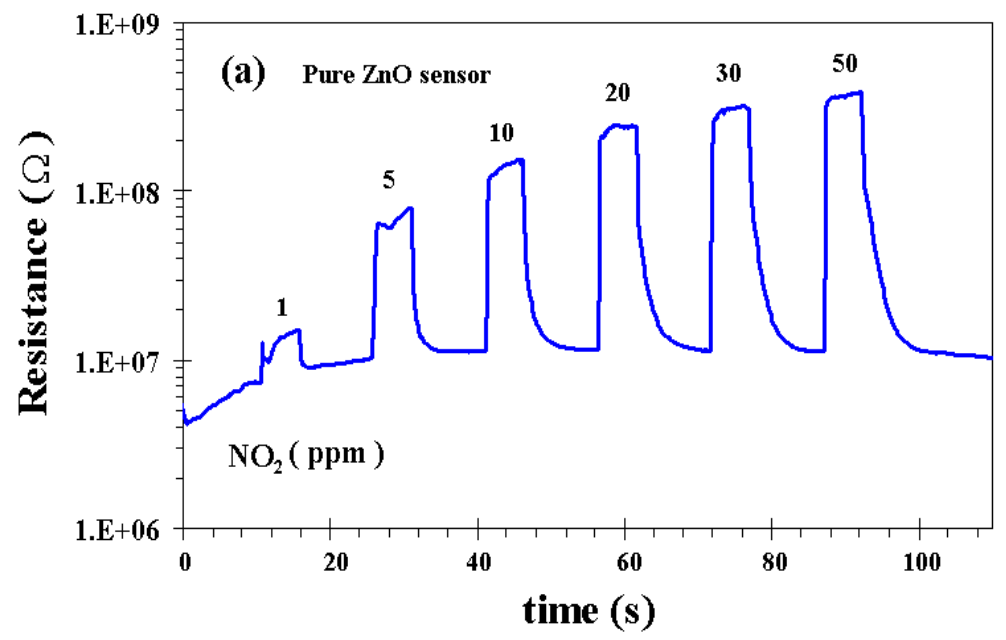

Ethanol $\left(\mathrm{C}_{2} \mathrm{H}_{5} \mathrm{OH}\right)$

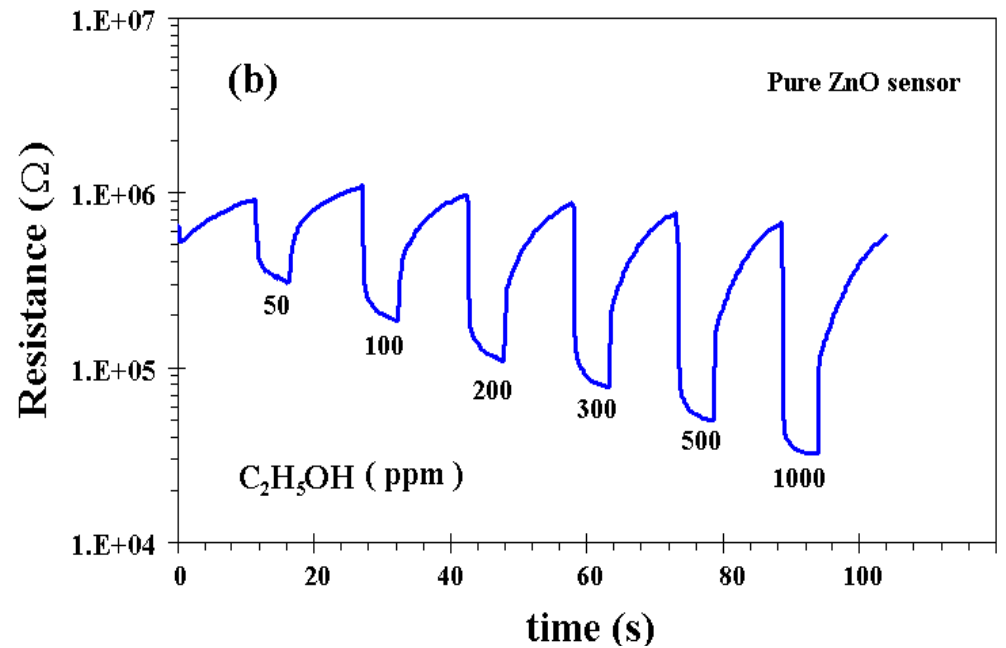

Sulfur dioxide $\left(\mathrm{SO}_{2}\right)$

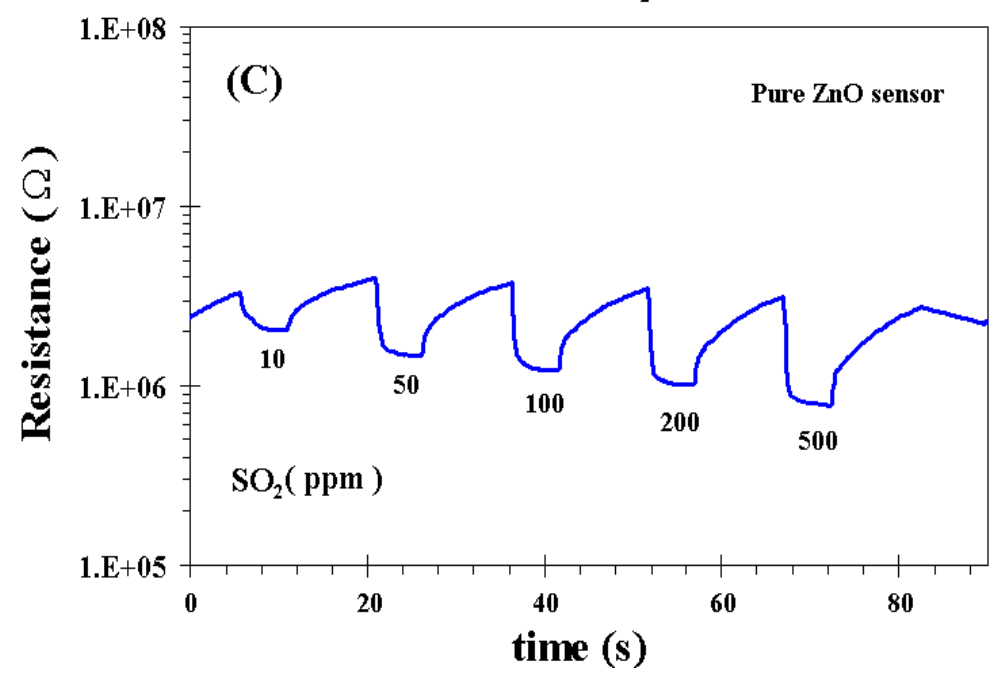


Figure 6. The sensitivity versus variation of the operating temperature of $\mathrm{NO}_{2}, \mathrm{C}_{2} \mathrm{H}_{5} \mathrm{OH}$ and $\mathrm{SO}_{2}$ (at $50 \mathrm{ppm}$ of concentration) for the undoped $\mathrm{ZnO}$ sensor.

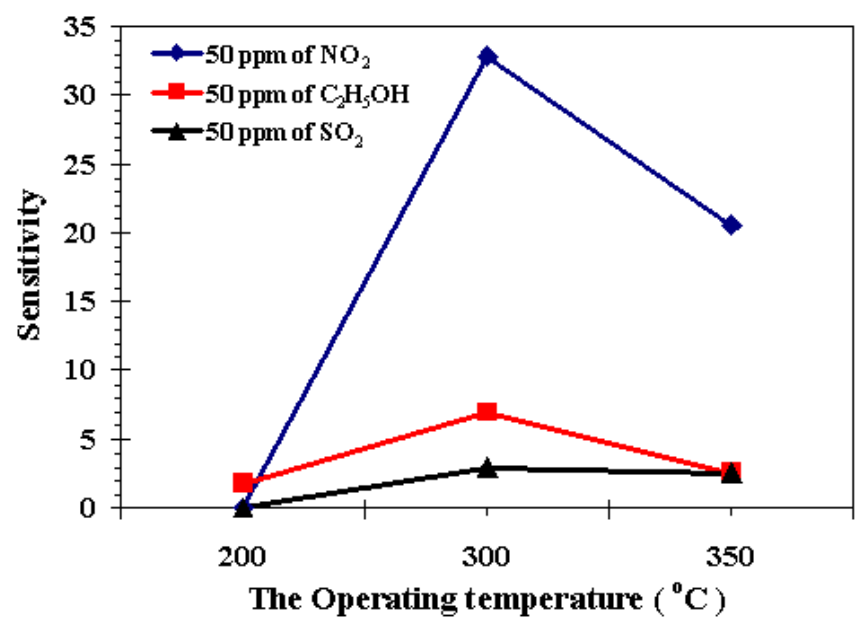

The gas sensing selectivity of the undoped $\mathrm{ZnO}$ gas sensor has been characterized towards one common oxidizing gas, nitrogen dioxide $\left(\mathrm{NO}_{2}\right)$, and two other common reducing gases, ethanol $\left(\mathrm{C}_{2} \mathrm{H}_{5} \mathrm{OH}\right)$ and sulfur dioxide $\left(\mathrm{SO}_{2}\right)$ as shown in Figure 7. In Figure 7, the sensitivities towards $\mathrm{NO}_{2}$, $\mathrm{C}_{2} \mathrm{H}_{5} \mathrm{OH}$ and $\mathrm{SO}_{2}$ under the operating temperature of $300{ }^{\circ} \mathrm{C}$ were found to be 33,7 and 3 , respectively. This indicates an excellent $\mathrm{NO}_{2}$ selectivity of our undoped $\mathrm{ZnO}$ gas sensor.

Figure 7. The sensitivity variation of the undoped $\mathrm{ZnO}$ sensor testing with $50 \mathrm{ppm}$ concentration of $\mathrm{NO}_{2}, \mathrm{C}_{2} \mathrm{H}_{5} \mathrm{OH}$ and $\mathrm{SO}_{2}$ under the operating temperature of $300{ }^{\circ} \mathrm{C}$.

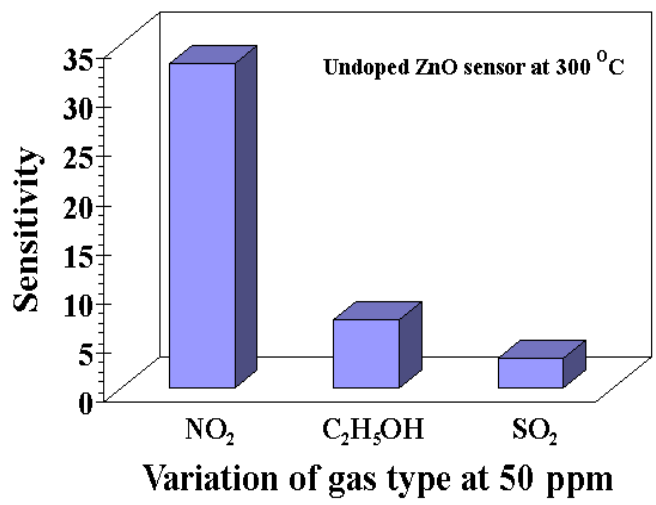

The sensitivities of the flame-made $\mathrm{ZnO}$ sensor towards different concentrations of $\mathrm{NO}_{2}, \mathrm{C}_{2} \mathrm{H}_{5} \mathrm{OH}$ and $\mathrm{SO}_{2}$ gases obtained from our studies are summarized in Table 3. In comparison with the previously reported sensitivities of other $\mathrm{ZnO}$ sensors given in Table 1 [21-24], the flame-made $\mathrm{ZnO}$ films showed higher sensitivity towards the same $\mathrm{NO}_{2}$ concentration in all cases. Sensitivity of flame-made $\mathrm{ZnO}$ films towards $100 \mathrm{ppm}$ of $\mathrm{SO}_{2}$ was 2.8, whereas the result from Lupan et al. [26] was less than 0.5. Likewise flame-made $\mathrm{ZnO}$ films showed sensitivity towards 200, 300 and $500 \mathrm{ppm}$ of ethanol as 18.2, 22.4 and 27.5 respectively which were higher than the values reported by Singh et al. [28] and Hieu et al. [31]. 
Table 3. Sensitivity of flame-made undoped $\mathrm{ZnO}$ nanoparticles towards different concentrations of $\mathrm{NO}_{2}, \mathrm{C}_{2} \mathrm{H}_{5} \mathrm{OH}$ and $\mathrm{SO}_{2}$ gases under the operating temperature of $300{ }^{\circ} \mathrm{C}$.

\begin{tabular}{cc}
\hline Gas concentration & Sensitivity \\
\hline $1,5,10,20,30$ and $50 \mathrm{ppm}$ of $\mathrm{NO}_{2}$ & $2.7,6.2,11.8,18.5,26.7$ and 33 \\
$100 \mathrm{ppm}$ of $\mathrm{SO}_{2}$ & 2.8 \\
200,300, and $500 \mathrm{ppm}$ of ethanol & $18.2,22.4$ and 27.5 \\
\hline
\end{tabular}

\section{Conclusions}

In summary, we have shown that FSP is a promising technique for the synthesis of high purity nano-sized materials with controlled size and crystallinity in a single step, exemplified by the fabrication of an undoped $\mathrm{ZnO}$ array sensor that can sense $\mathrm{NO}_{2}, \mathrm{C}_{2} \mathrm{H}_{5} \mathrm{OH}$ and $\mathrm{SO}_{2}$ gases. The undoped ZnO-based $\mathrm{NO}_{2}$ gas sensor showed the lowest detection limit of $1 \mathrm{ppm}$ with short response and recovery time. Moreover, the sensors showed a high selectivity towards $\mathrm{NO}_{2}$ at $300{ }^{\circ} \mathrm{C}$ when compared with $\mathrm{C}_{2} \mathrm{H}_{5} \mathrm{OH}$ and $\mathrm{SO}_{2}$ gases, respectively. The sensitivity of undoped $\mathrm{ZnO}$ film towards 50 ppm of $\mathrm{NO}_{2}, \mathrm{C}_{2} \mathrm{H}_{5} \mathrm{OH}$ and $\mathrm{SO}_{2}$ were 33,7 and 3 respectively.

\section{Acknowledgements}

The authors gratefully acknowledge the financial support from the Office of Higher Education Commision, Ministry of Education; the Graduate School and Department of Chemistry, Faculty of Science, Chiang Mai University, Thailand; the National Nanotechnology Center and the National Electronics and Computer Technology Center, Pathumthani, Thailand.

\section{References}

1. Cheng, X.L.; Zhao, H.; Huo, L.H.; Gao, S.; Zhao, J.G. ZnO nanoparticulate thin film: Preparation, characterization and gas-sensing property. Sens. Actuat. B Chem. 2004, 102, 248-252.

2. Nunes, P.; Fernandes, B.; Fortunato, E.; Vilarinho, P.; Martins, R. Performances presented by zinc oxide thin films deposited by spray pyrolysis. Thin Solid Films 1999, 337, 176-179.

3. Jiaqiang, X.; Yuping, C.; Yadong, L.; Jianian, S. Gas sensing properties of ZnO nanorods prepared by hydrothermal method. J. Mater. Sci. 2005, 40, 2919-2921.

4. Baruwati, B.; Kumar, D.K.; Manorama, S.V. Hydrothermal synthesis of highly crystalline $\mathrm{ZnO}$ nanoparticles: A competitive sensor for LPG and EtOH, Sens. Actuat. B Chem. 2006, 119, 676-682.

5. Li, D.; McCann, J.T.; Xia, Y. Electrospinning: A simple and versatile technique for producing ceramic nanofibers and nanotubes. J. Am. Ceram. Soc. 2006, 89, 1861-1869.

6. Gao, T.; Wang, T.H. Synthesis and properties of multipod-shaped $\mathrm{ZnO}$ nanorods for gas-sensor applications. Appl. Phys. A 2005, 80, 1451-1454.

7. Umar, A.; Suh, E.K.; Hahn, Y.B. Growth and optical properties of large-quantity single-crystalline ZnO rods by thermal evaporation. J. Phys. D 2007, 40, 3478-3484. 
8. Sun, Z.P.; Liu, L.; Zhang, L.; Jia, D.Z. Rapid synthesis of ZnO nano-rods by onestep room-temperature, solid-state reaction and their gas-sensing properties. Nanotechnology 2006, 17, 2266-2270.

9. Rout, C.S.; Krishna, S.H.; Vivekchand, S.R.C.; Govindaraj, A.; Rao, C.N.R. Hydrogen and ethanol sensors based on $\mathrm{ZnO}$ nanorods, nanowires and nanotubes. Chem. Phys. Lett. 2006, 418, $586-590$.

10. Li, C.; Li, L.; Du, Z.; Yu, H.; Xinag, Y.; Li, Y.; Cai, Y.; Wang, T. Rapid and ultrahigh ethanol sensing based on Au-coated $\mathrm{ZnO}$ nanorods. Nanotechnology 2008, 19, 35501-1-35501-4.

11. Chen, Y.; Zhu, C.L.; Xiao, G. Reduced-temperature ethanol sensing characteristics of flower-like $\mathrm{ZnO}$ nanorods synthesized by a sonochemical method. Nanotechnology 2006, 17, 4537-4541.

12. Guo, G.; Guo, J.; Tao, D.; Choy, W.C.H.; Zhao, L.; Qian, W.; Wang, Z. A simple method to prepare multi-walled carbon nanotubes/ZnO nanoparticles composites. Appl. Phys. A 2007, 89, 525-528.

13. Yu, K.; Zhang, Y.; Luo, L.; Wang, W.; Zhu, Z.; Wang, J.; Cui, Y.; Ma, H.; Lu, W. Growth and optical properties of quadrangular zinc oxide nanorods on copper-filled porous silicon. Appl. Phys. A 2004, 79, 443-446.

14. Maedler, L.; Kammler, H.K.; Mueller, R.; Pratsinis, S.E. Controlled synthesis of nanostructured particles by flame spray pyrolysis. J. Aerosol. Sci. 2002, 33, 369-389.

15. Gergintschew, Z.; Forster, H.; Kositza, J.; Schipanski, D. Two-dimensional numerical simulation of semiconductor gas sensors. Sens. Actuat. B Chem. 1995, 26, 170-173.

16. Egashira, M.; Shimizu, Y.; Takao, Y.; Sako, S. Variations in I-V characteristics of oxide semiconductors induced by oxidizing gases. Sens. Actuat. B Chem. 1996, 35-36, 62-67.

17. Xu, J.; Pan, Q.; Shun, Y.; Tian, Z. Grain size control and gas sensing properties of ZnO gas sensor. Sens. Actuat. B Chem. 2000, 66, 277-279.

18. Koshizaki, N.; Oyama, T. Sensing characteristics of ZnO-based NO sensor. Sens. Actuat. B Chem. 2000, 66, 119-121.

19. Rao, G.S.T.; Rao, D.T. Gas sensitivity of $\mathrm{ZnO}$ based thick film sensor to $\mathrm{NH}_{3}$ at room temperature. Sens. Actuat. B Chem. 1999, 55, 166-169.

20. Law, M.; Kind, H.; Kim, F.; Messer, B.; Yang, P. Photochemical sensing of $\mathrm{NO}_{2}$ with $\mathrm{SnO}_{2}$ nanoribbon nanosensors at room temperature. Angew. Chem. Int. Ed. 2002, 41, 2405-2408.

21. Ghimbeu, C.M.; Schoonman, J.; Lumbreras, M.; Siadat, M. Electrostatic spradeposited zinc oxide films for gas sensor applications. Appl. Surf. Sci. 2007, 253, 7483-7489.

22. Cho, P.S.; Kim, K.W.; Lee, J.H. $\mathrm{NO}_{2}$ sensing characteristics of $\mathrm{ZnO}$ nanorods prepared by hydrothermal method. J. Electroceram. 2006, 17, 975-978.

23. Sadek, A.Z.; Wlodarski, W.; Kalantar-zadeh, K.; Choopun, S. ZnO Nanobelt Based Conductometric $\mathrm{H}_{2}$ and $\mathrm{NO}_{2}$ Gas Sensors. IEEE Sens. J. 2005, doi: 10.1109/ICSENS.2005. 1597952.

24. Sadek, A.Z.; Choopun, S.; Wlodarski, W.; Ippolito, S.J.; Kalantar-zadeh, K. Characterization of $\mathrm{ZnO}$ nanobelt-based gas sensor for $\mathrm{H}_{2}, \mathrm{NO}_{2}$, and hydrocarbon sensing. J. IEEE Sens. 2007, 7, 919-924.

25. Koshizaki, N.; Oyama, T. Sensing characteristics of ZnO-based NO sensor. Sens. Actuat. B Chem. 2000, 66, 119-121. 
26. Lupan, O.; Chow, L.; Chai, G. A single ZnO tetrapod-based sensor. Sens. Actuat. B Chem. 2009, $141,511-517$.

27. Zhang, W.D.; Zhang, W.H.; Ma, X.Y. Tunable ZnO nanostructures for ethanol sensing. J. Mater. Sci. 2009, 44, 4677-4682.

28. Singh, R.C.; Singh, O.; Singh, M.P.; Chandi, P.S. Synthesis of zinc oxide nanorods and nanoparticles by chemical route and their comparative study as ethanol sensors. Sens. Actuat. B Chem. 2008, 135, 352-357.

29. Jing, Z.; Zhan, J. Fabrication and gas-sensing properties of porous $\mathrm{ZnO}$ nanoplates. Adv. Mater. 2008, 20, 4547-4551.

30. Xu, J.; Zhang, Y.; Chen, Y.; Xiang, Q.; Pan, Q.; Shi, L. Uniform ZnO nanorods can be used to improve the response of $\mathrm{ZnO}$ gas sensor. Mater. Sci. Eng. B 2008, 150, 55-60.

31. Hieu, N.V.; Chien, N.D. Low-temperature growth and ethanol-sensing characteristics of quasi-one-dimensional $\mathrm{ZnO}$ nanostructures. Phys. B 2008, 403, 50-56.

32. Oh, E.; Choi, H.-Y.; Jung, S.-H.; Cho, S.; Kim, J.C. Lee, K.-H.; Kang, S.-W.; Kim, J.; Yun, J.-Y. High-performance $\mathrm{NO}_{2}$ gas sensor based on $\mathrm{ZnO}$ nanorod grown by ultrasonic irradiation. Sens. Actuat. B Chem. 2009, 141, 239-243.

33. Wan, Q.; Li, Q.H.; Chen, Y.J.; He, X.L.; Li, J.P.; Lin, C.L.; Wang, T.H. Fabrication and ethanol sensing characteristics of $\mathrm{ZnO}$ nanowire gas sensors. Appl. Phys. Lett. 2004, 84, 3654-3656.

34. Shinde, V.R.; Gujar, T.P.; Lokhande C.D. Enhanced response of porous $\mathrm{ZnO}$ nanobeads towards LPG:Effect of Pd sensitization. Sens. Actuat. B Chem. 2007, 123, 701-706.

35. Gonga, H.; Hua, J.Q.; Wang, J.H.; Onga, C.H.; Zhub, F.R. Nano-crystalline Cu-doped ZnO thin film gas sensor for CO. Sens. Actuat. B Chem. 2006, 115, 247-251.

(C) 2010 by the authors; licensee MDPI, Basel, Switzerland. This article is an Open Access article distributed under the terms and conditions of the Creative Commons Attribution license (http://creativecommons.org/licenses/by/3.0/). 